\title{
Tepidimonas ignava gen. nov., sp. nov., a new chemolithoheterotrophic and slightly thermophilic member of the $\beta$-Proteobacteria
}

\author{
Claudia Moreira, ${ }^{1}$ Fred A. Rainey, ${ }^{2}$ M. Fernanda Nobre, ${ }^{1}$ \\ Manuel T. da Silva ${ }^{3}$ and Milton S. da Costa ${ }^{1}$
}

1 Centro de Neurociências e
Biologia Celular,
Departamento de
Zoologia, Universidade de
Coimbra, 3004-517
Coimbra, Portugal
2 Department of Biological
Sciences, Louisiana State
University, Baton Rouge,
LA 70803, USA
3 Instituto de Biologia
Molecular e Celular,
Universidade do Porto,
R. do Campo Alegre,
4150 Porto, Portugal

Author for correspondence: Milton S. da Costa. Tel: +351 39 824024. Fax: + 35139826798.

e-mail:milton@cygnus.ci.uc.pt

\begin{abstract}
A bacterial isolate with an optimum growth temperature of about $55{ }^{\circ} \mathrm{C}$ was recovered on a medium composed of one part Kligler's iron agar and four parts of Thermus Agar from the hot spring at São Pedro do Sul in central Portugal. Phylogenetic analyses using the 16S rRNA gene sequence of strain SPS-1037 indicated that the new organism represented a new genus and species of $\beta$-Proteobacteria. The major fatty acids of strain SPS-1037 are C16:0 and C17:0. Ubiquinone 8 is the major respiratory quinone, and the major polar lipids are phosphatidylethanolamine and phosphatidylglycerol. The new isolate is aerobic and chemolithoheterotrophic. Thiosulfate and tetrathionate were oxidized to sulfate. The growth yield of the organism was improved by the addition of thiosulfate to media containing organic carbon sources, but the organism did not grow autotrophically under the conditions examined.

Heterotrophic growth of strain SPS-1037 occurs on amino acids and organic acids, but this organism does not assimilate carbohydrates. On the basis of the phylogenetic analyses, and physiological and biochemical characteristics, it is proposed that strain SPS-1037 represents a new genus and a new species for which the name Tepidimonas ignava is proposed.
\end{abstract}

Keywords: Tepidimonas ignava, $\beta$-Proteobacteria, thermophile

\section{INTRODUCTION}

The deeply branching lines of descent within the domain Bacteria are, in contrast to the most recent lineages, primarily composed of thermophilic species. Thus far, the phylum Aquifex-Hydrogenobacter, and the order Thermotogales, for example, contain hyperthermophilic, thermophilic and slightly thermophilic species. Many of the species of the green non-sulfur bacteria and of the Deinococcus-Thermus phyla are also thermophilic. On the other hand, the vast majority of the species belonging to the most recent lines of descent, such as the Proteobacteria, are mesophilic. There are, of course, exceptions and slightly thermophilic, moderately thermophilic and even extremely

Abbreviations: FAME, fatty acid methyl ester; GYM, glutamine/yeast extract medium.

The EMBL accession number for the 16S rRNA sequence of Tepidimonas ignava strain SPS- $1037^{\top}$ is AF177943. thermophilic species have been described from these bacterial lineages. The $\beta$-subclass of the Proteobacteria, for example, includes many mesophilic species, but it also includes a few slightly thermophilic species, namely Thiomonas thermosulfata (Shooner et al., 1996; Moreira \& Amils, 1997), and the thermophilic species Thermothrix thiopara (Caldwell et al., 1976) and Thermothrix azorensis (Odintsova et al., 1996). Many $\beta$-Proteobacteria oxidize inorganic sulfur compounds and it may not come as a surprise that the thermophilic species of this subclass also share this characteristic. Nevertheless, strict chemo-organotrophs, capable of growth at high temperatures, have not yet been described within the $\beta$-Proteobacteria. The species of the genus Thermothrix are obligately or facultatively chemolithoautotrophic, while the species of the genus Thiomonas are facultative chemolithoautotrophs. The species of these genera are not closely related to each other, and there may be no relationship between sulfur chemolithotrophy and the ability of organisms to grow at high temperatures. 
We recently isolated one slightly thermophilic organism from the hot spring runoff at São Pedro do Sul on a medium composed of a mixture of Thermus medium and Kligler's iron agar. The organism is aerobic and chemolithoheterotrophic with an optimum growth temperature of about $55^{\circ} \mathrm{C}$. Phylogenetic analysis showed that the strain belonged to the $\beta$ Proteobacteria, but was unrelated to any of the known genera. On the basis of these results and of the biochemical, physiological and chemotaxonomic characteristics we propose that strain SPS- $1037^{\mathrm{T}}$ represents a new genus and species which we name Tepidimonas ignava.

\section{METHODS}

Isolation and bacterial strains. Strain SPS- $1037^{\mathrm{T}}$ was isolated from an artificial runoff of the hot spring located near São Pedro do Sul in central Portugal. Water samples were transported without temperature control and filtered the same day through membrane filters (Gelman type GN-6, pore size $0.45 \mu \mathrm{m}$, diameter $47 \mathrm{~mm}$ ); the filters were placed on the surface of a solid medium composed of four parts Thermus medium (Williams \& da Costa, 1992) and one part of Kligler's iron agar (Difco). These preparations were wrapped in plastic bags and incubated at $60^{\circ} \mathrm{C}$ for up to $4 \mathrm{~d}$. Cultures were purified by subculturing on medium 162 (Degryse et al., 1978) containing $2.5 \mathrm{~g}$ tryptone $1^{-1}$ and $2.5 \mathrm{~g}$ yeast extract $1^{-1}$ and were stored at $-70{ }^{\circ} \mathrm{C}$ in the same medium with $15 \%(\mathrm{w} / \mathrm{v})$ glycerol. Bosea thiooxidans (DSM 9653 ${ }^{\mathrm{T}}$ ) and Thiobacillus tepidarius (DSM 3134 ${ }^{\mathrm{T}}$ ) were obtained from the Deutsche Sammlung von Mikroorganismen und Zellkulturen, Braunschweig, Germany and used as controls for the utilization of reduced sulfur compounds by strain SPS-1037 ${ }^{\mathrm{T}}$.

Morphological, biochemical and tolerance characteristics. Electron microscopy was performed on exponential phase cultures. Cells were fixed with aqueous $4 \%$ paraformaldehyde, $1.25 \%$ glutaraldehyde and $10 \mathrm{mM}$ calcium chloride fixative at room temperature. The cells were washed after $4 \mathrm{~h}$ with $50 \mathrm{mM}$ cacodylate buffer supplemented with $10 \mathrm{mM}$ calcium chloride ( $\mathrm{pH} \mathrm{6.4)}$ and fixed at room temperature for $2 \mathrm{~h}$ with osmium tetroxide in veranol acetate buffer containing $10 \mathrm{mM}$ calcium chloride (Silva \& Macedo, 1983, 1987). The samples were embedded in Epon after dehydration in ethanol. The sections were routinely contrasted with uranyl acetate followed by lead citrate. Observations and micrographs were performed with a Zeiss EM10C electron microscope. Cells dimensions and motility were determined by phase-contrast microscopy. The number and the position of flagella were visualized by light microscopy after staining of the cells with the Ryu stain (Heimbrook et al., 1989).

Unless otherwise stated, all biochemical and tolerance tests were performed as described previously (Santos et al., 1989, Nunes et al., 1992) in Degryse 162 liquid medium or Degryse 162 agar at $55^{\circ} \mathrm{C}$ for up $5 \mathrm{~d}$. The growth temperature range of strains SPS $-1037^{\mathrm{T}}$ was examined by measuring the turbidity $(610 \mathrm{~nm})$ of cultures incubated in $300 \mathrm{ml}$ metalcapped Erlenmeyer flasks, containing $100 \mathrm{ml}$ Degryse medium in a reciprocal water-bath shaker. The $\mathrm{pH}$ range for growth was examined at $55^{\circ} \mathrm{C}$ in the same medium using $20 \mathrm{mM}$ MES for $\mathrm{pH}$ values between 5.0 and 6.5, $20 \mathrm{mM}$ Tris for $\mathrm{pH}$ values between $7 \cdot 0$ and 8.5 , and $20 \mathrm{mM}$ CAPSO [3- (cyclohexylamino)-2-hydroxy-1-propanesulfonic acid] for $\mathrm{pH}$ values between 9.0 and 10.5 ; the $\mathrm{pH}$ of each buffer was adjusted with $\mathrm{HCl}$ or $\mathrm{NaOH}$. The $\mathrm{pH}$ values of the cultures were determined at room temperature. Control media, containing each buffer adjusted to $\mathrm{pH} 7 \cdot 5$, were used to assess possible inhibitory effects of the buffering agents.

Single-carbon-source assimilation tests were performed in a minimal medium composed of Degryse 162 basal salts containing a filter-sterilized vitamin/amino acid solution (Sharp \& Williams, 1988), ammonium sulfate $\left(0.5 \mathrm{~g} \mathrm{l}^{-1}\right)$ and the carbon sources $\left(2 \cdot 0 \mathrm{~g}^{-1}\right)$. Growth was examined daily by measuring the turbidity of cultures incubated at $55^{\circ} \mathrm{C}$ in $20 \mathrm{ml}$ screw-capped tubes containing $10 \mathrm{ml}$ medium for a total of $7 \mathrm{~d}$. Positive and negative control cultures were grown in medium 162 and in minimal medium without carbon source.

Growth on reduced sulfur compounds. Strain SPS $-1037^{\mathrm{T}}$ was grown in glutamate/yeast extract medium (GYM) previously used for the growth of Bosea thiooxidans (Das et al., 1996), containing $2 \cdot 5 \mathrm{~g}$ succinate $1^{-1}$ and the vitamin/amino acid solution of Sharp \& Williams (1988), and medium 69 (Deutsche Sammlung von Mikroorganismen und Zellkulturen, 1993) containing $1 \mathrm{~g}$ yeast extract $1^{-1}$. Thiosulfate was added to each of these media at concentrations that varied between 0.5 and $5 \cdot 0 \mathrm{~g} \mathrm{l}^{-1}$. Bosea thiooxidans was cultivated at $30{ }^{\circ} \mathrm{C}$ and strain SPS- $1037^{\mathrm{T}}$ was cultivated at $55^{\circ} \mathrm{C}$. At appropriate intervals, the turbidity of the cultures was determined and the cells were harvested by filtration through Gelman type GN-6 membrane filters. The levels of thiosulfate and sulfate in the filtrates were determined using the methods described by Westley (1987) and Sörbo (1987), respectively.

Polar lipid, lipoquinone and fatty acid composition. The cultures used for polar lipid and lipoquinone analyses were grown on Degryse 162 medium at $55^{\circ} \mathrm{C}$ until the exponential phase of growth. The cells were removed from the surface of the Petri dishes and the extraction of lipids was performed as described previously (Prado et al., 1988). The individual polar lipids were separated by mono-dimensional TLC on silica gel $\mathrm{G}$ plates (Merck; $0.25 \mathrm{~mm}$ thickness) with a solvent system consisting of chloroform/methanol/acetic acid/ water $(80: 12: 15: 4$, by vol.).

Lipoquinones were extracted from freeze-dried cells and purified by TLC as described by Tindall (1989). They were separated with a Gilson HPLC apparatus by using a reversephase column (RP18, Spherisorb, S5 ODS2) with methanol/ heptane $(10: 2, \mathrm{v} / \mathrm{v})$ as the mobile phase and were detected at $269 \mathrm{~nm}$.

Cultures for fatty acid analysis were grown on Degryse 162 agar plates in sealed plastic bags submerged in a water bath at $55^{\circ} \mathrm{C}$ for $24 \mathrm{~h}$. Fatty acid methyl esters (FAMEs) were obtained from fresh wet biomass by saponification, methylation and extraction as described by Kuykendall (1988). The FAMEs were separated using a Hewlett Packard model 5890 gas chromatograph equipped with a flameionization detector fitted with a $5 \%$ phenylmethyl silicone capillary column $(0.2 \mathrm{~mm} \times 25 \mathrm{~m}$; Hewlett Packard). The carrier gas was high purity $\mathrm{H}_{2}$, the column head pressure was $60 \mathrm{KPa}$, the septum purge was $5 \mathrm{ml} \mathrm{min}^{-1}$, the column split ratio was $55: 1$ and the injection port temperature was $300{ }^{\circ} \mathrm{C}$. The temperature of the oven was programmed from $170-270{ }^{\circ} \mathrm{C}$ at a rate of $5^{\circ} \mathrm{C} \mathrm{min}^{-1}$. Identification and quantification of the FAMEs, as well as the numerical analysis of the fatty acid profiles, were performed by using 


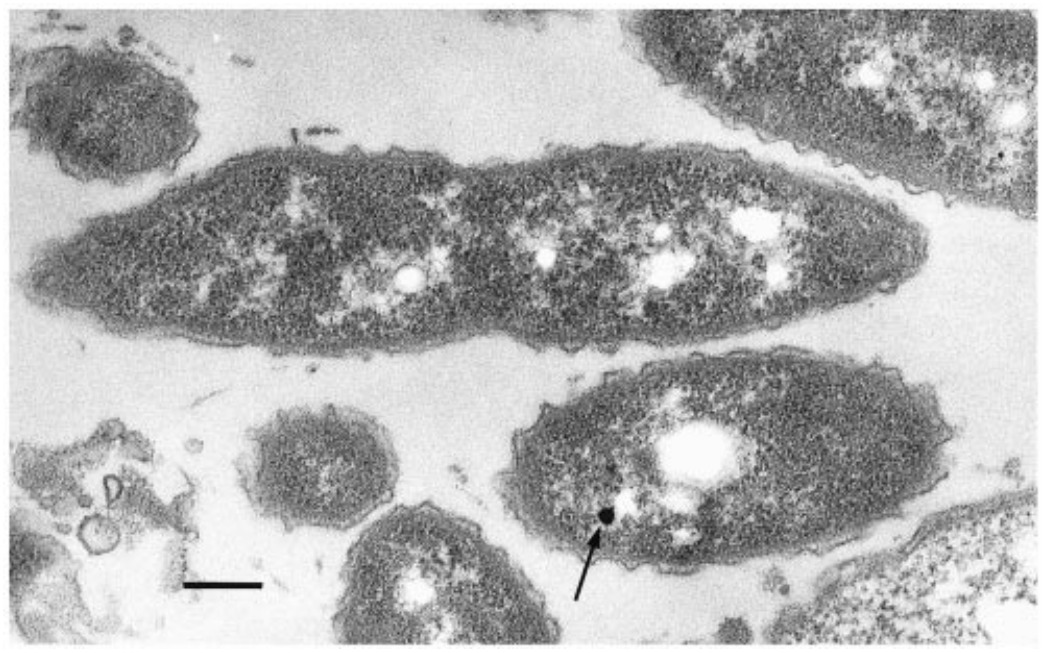

Fig. 1. Ultrastructure of strain SPS $1037^{\top}$. The arrow shows a polyphosphate inclusion. Bar, $0 \cdot 20 \mu \mathrm{m}$.

the standard MIS Library Generation Software (Microbial ID).

Determination of $G+C$ content of DNA and 16S rRNA gene sequence, and phylogenetic analysis. DNA was isolated as described by Cashion et al. (1977). The G $+C$ content of DNA was determined by HPLC as described by Mesbah et al. (1989).

Extraction of genomic DNA for 16S rRNA gene sequence determination, PCR amplification of the 16S rRNA gene and sequencing of the purified PCR products was carried out as described previously (Rainey et al., 1996). Purified sequencing-reaction products were electrophoresed using a model 310 Genetic Analyzer (Applied Biosystems). The 16S rRNA gene sequence obtained in this study was aligned against the previously determined $\beta$-Proteobacteria sequences available from the public databases using the ae2 editor (Maidak et al., 1999). The method of Jukes \& Cantor (1969) was used to calculate evolutionary distances. Phylogenetic dendrograms were generated using various treeing algorithms contained in the PHYLIP package (Felsenstein, 1993).

Nucleotide sequence accession numbers. The $16 \mathrm{~S}$ rRNA gene sequence determined in this study was deposited with EMBL under accession number AF177943. The accession numbers of the reference sequences used in the phylogenetic analyses are as follows: Alcaligenes faecalis, M22508; Alcaligenes xylosoxidans, M22509; Azoarcus indigens, L15531; Brachymonas denitrificans, D14320; Bordetella bronchiseptica, U04948; Burkholderia cepacia, M22518; Chromobacterium violaceum, M22510; Comamonas testosteroni, M11224; Eikenella corrodens, M22512; Escherichia coli, J01695; Gallionella ferruginea, L07897; Ideonella dechloratans, X72724; Iodobacter fluviatilis, M22511; Janthinobacterium lividum, Y08846; Kingella kingae, M22517; Leptothrix discophora, Z18533; Nitrosomonas europaea, M96399; Ralstonia eutropha, D88000; Rhodocyclus purpureus, M34132; Rhodoferax fermentans, D16211; Simonsiella muelleri, M59071; Sphaerotilis natans, Z18534; Spirillum volutans, M34131; Taylorella equigenitalis, X68645; Telluria mixta, X65589; Telluria chitinolytica, X65590; Vitreoscilla stercoraria, M22519; strain ac-15, U46749; strain ac-16, U46748; strain BrG4, U51104.

\section{RESULTS}

\section{Isolation, morphological and biochemical characteristics of strain SPS-1037}

Different proportions of Kligler's iron agar, a medium generally used for the differentiation of enteric bacteria based on fermentation of dextrose and lactose, and production of hydrogen sulfide, were added to Thermus medium to make the latter more selective. One Gram-negative organism was isolated, among several colonies of spore-forming bacteria after incubation of a 4:1 mixture of Thermus/Kligler's iron agar. Higher proportions of Kligler's iron agar led to the isolation of spore-forming bacteria alone or did not lead to the isolation of any organisms after $4 \mathrm{~d}$ incubation at $60^{\circ} \mathrm{C}$. The temperature of the site at São Pedro do Sul from which the organism was recovered was $58^{\circ} \mathrm{C}$ and the $\mathrm{pH}$ was $8 \cdot 4$. Two further attempts to isolate this organism on the same medium from the same site failed.

Strain SPS- $1037^{\mathrm{T}}$ formed very short, Gram-negative, rod-shaped cells and possessed one polar flagellum. Colonies were non-pigmented and translucent. Strain SPS- $1037^{\mathrm{T}}$ had an envelope composed of an outer membrane with a triple-layer structure and a very thin peptydoglycan layer visible between the cytoplasmic membrane and the outer membrane (Fig. 1). Polyphosphate inclusions were also visible in the electron micrographs.

The optimum growth temperature of strain SPS-1037 in Degryse medium 162 was between 50 and $55^{\circ} \mathrm{C}$, with a maximum growth temperature of between 60 and $65{ }^{\circ} \mathrm{C}$ (Fig. 2). The optimum $\mathrm{pH}$ for growth was about $\mathrm{pH} 7 \cdot 5-8 \cdot 5$. Strain SPS- $1037^{\mathrm{T}}$ was strictly aerobic and did not reduce nitrate or nitrite under anaerobic conditions. Yeast extract or a vitamin/ amino acid solution was required for growth on single carbon sources. With the exception of hide powder azure, proteins were not degraded, but urease was 


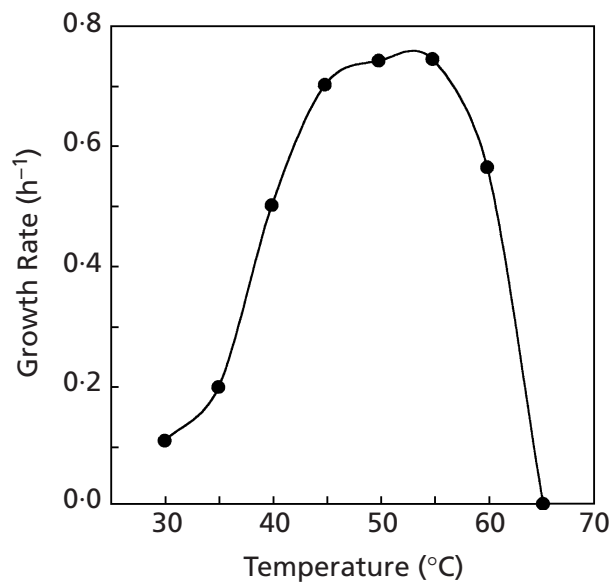

Fig. 2. Effect of the temperature on the growth of strain SPS $1037^{\top}$.

present. One of the most interesting characteristics of this organism was its inability to utilize any of the hexoses, pentoses, disaccharides or polyols tested. In fact, strain SPS $-1037^{\mathrm{T}}$ was able to grow only on amino acids and organic acids (Table 1 ). The $\mathrm{G}+\mathrm{C}$ content of the DNA was $69 \cdot 7 \mathrm{~mol} \%$.

Initial observations indicated that strain SPS-1037 produced sulfate from thiosulfate and tetrathionite, but not from cysteine or thioglycolate. To investigate the role of thiosulfate as an electron donor we used Bosea thiooxidans and Thiobacillus tepidarius, known to be chemolithoheterotrophic or facultatively chemolithoautotrophic on reduced sulfur compounds, respectively, as controls. In contrast to Thiobacillus tepidarius, strain SPS-1037 10 was incapable of growth on mineral medium containing thiosulfate, supplemented with yeast extract $\left(100 \mathrm{mg} \mathrm{l}^{-1}\right)$, or without yeast extract, added as a source of growth factors. The addition of thiosulfate $\left(1.0 \mathrm{~g}\right.$ and $\left.5.0 \mathrm{~g}^{-1}\right)$ to medium 69 containing $1 \mathrm{~g}$ yeast extract $1^{-1}$ lead to an increase in the biomass of strain SPS- $1037^{\mathrm{T}}$ indicating that thiosulfate was used as an energy source in the presence of organic substrates (Table 2). In contrast to Bosea thiooxidans (Das et al., 1996), an increase in the final biomass of strain SPS-1037 $7^{\mathrm{T}}$ was not observed in GYM containing $2.5 \mathrm{~g}$ succinate $1^{-1}$ to which thiosulfate was added. The determination of the levels of

Table 1. Characteristics of strain SPS-1037

+ , Positive result or growth; w, weak positive result; -, negative result or no growth.

\begin{tabular}{|c|c|c|c|c|c|c|c|c|c|}
\hline Presence of: & & Growth in: & & $\begin{array}{l}\text { Utilization of } \\
\text { carbon } \\
\text { source: }\end{array}$ & & & & & \\
\hline Catalase & $\mathrm{W}$ & $1 \% \mathrm{NaCl}$ & + & D-Arabinose & - & Ethanol & - & Glycine & - \\
\hline Oxidase & + & $2 \% \mathrm{NaCl}$ & - & L-Arabinose & - & Glycerol & - & L-Alanine & + \\
\hline DNase & - & & & D-Fructose & - & i-Erythritol & - & L-Cysteine & - \\
\hline Xylanase & - & Hydrolysis of: & & D-Ribose & - & D-Arabitol & - & L-Serine & + \\
\hline$\alpha$-Galactosidase & - & Arbutin & - & D-Xylose & - & Ribitol & - & L-Asparagine & + \\
\hline$\beta$-Galactosidase & - & Aesculin & - & L-Fucose & - & Xylitol & - & L-Aspartate & + \\
\hline$\alpha$-Glucosidase & - & Gelatin & - & D-Galactose & - & D-Mannitol & - & L-Threonine & $\mathrm{W}$ \\
\hline$\beta$-Glucosidase & - & Elastin & - & D-Glucose & - & D-Sorbitol & - & L-Glutamate & + \\
\hline $\begin{array}{l}p \text {-nitrophenyl } \\
\text { palmitate }\end{array}$ & + & Fibrin & - & D-Mannose & - & myo-Inositol & - & L-Glutamine & + \\
\hline $\begin{array}{l}p \text {-nitrophenyl } \\
\text { laurate }\end{array}$ & + & $\begin{array}{l}\text { Hide Powder } \\
\text { Azure }\end{array}$ & + & L-Rhamnose & - & Acetate & + & L-Leucine & + \\
\hline $\mathrm{PHB} \dagger$ & - & Casein & - & L-Sorbose & - & Glycerate & - & L-Methionine & - \\
\hline Indole & - & Starch & - & Sucrose & - & Lactate & + & L-Proline & + \\
\hline \multirow[t]{2}{*}{ Urease } & + & Hippurate & - & D-Cellobiose & - & Pyruvate & + & L-Valine & - \\
\hline & & Tween 20 & - & Lactose & - & Fumarate & + & L-Arginine & - \\
\hline \multirow[t]{2}{*}{ Reduction of nitrate } & - & Tween 40 & - & Maltose & - & Malate & + & L-Histidine & - \\
\hline & & Tween 60 & - & D-Melibiose & - & Succinate & + & L-Isoleucine & W \\
\hline \multirow{2}{*}{$\begin{array}{l}\text { Anaerobic growth } \\
\text { with nitrate }\end{array}$} & - & Tween 80 & - & D-Trehalose & - & Oxaloacetate & + & L-Lysine & - \\
\hline & & & & D-Raffinose & - & $\alpha$-Ketoglutarate & + & L-Phenylalanine & - \\
\hline \multirow[t]{2}{*}{ MRVP* } & - & & & $\begin{array}{l}N \text {-Acetyl- } \\
\text { glucosamine }\end{array}$ & - & & & L-Tryptophan & - \\
\hline & & & & & & & & L-Ornithine & + \\
\hline
\end{tabular}

* Methyl Red Voges-Proskauer.

$\dagger$ Poly- $\beta$-hydroxybutyrate. 
Table 2. Effect of the medium and the initial concentration of thiosulfate on the growth of Bosea thiooxidans and strain SPS-1037

The maximum turbidity of Bosea thiooxidans was reached after 50 and $90 \mathrm{~h}$ growth at $30^{\circ} \mathrm{C}$ in GYM and medium 69, respectively. The maximum turbidity of strain SPS- $1037^{\mathrm{T}}$ was reached after 55 and $30 \mathrm{~h}$ at $55^{\circ} \mathrm{C}$ in GYM and medium 69, respectively.

\begin{tabular}{|c|c|c|c|}
\hline \multirow[t]{2}{*}{ Medium } & \multirow[t]{2}{*}{$\begin{array}{c}\mathrm{Na}_{2} \mathrm{~S}_{2} \mathrm{O}_{3} \\
\quad\left(\mathrm{~g} \mathrm{l}^{-1}\right)\end{array}$} & \multicolumn{2}{|c|}{$\begin{array}{c}\text { Maximum } \\
\text { turbidity }\end{array}$} \\
\hline & & Bosea thiooxidans & SPS-1037 ${ }^{\mathrm{T}}$ \\
\hline \multirow[t]{3}{*}{ GYM } & 0 & $0 \cdot 62$ & $0 \cdot 55$ \\
\hline & 1 & 0.98 & $0 \cdot 47$ \\
\hline & 5 & $1 \cdot 33$ & $0 \cdot 48$ \\
\hline \multirow[t]{3}{*}{69} & 0 & 0.74 & $0 \cdot 19$ \\
\hline & 1 & 0.79 & $0 \cdot 26$ \\
\hline & 5 & $1 \cdot 12$ & $0 \cdot 41$ \\
\hline
\end{tabular}

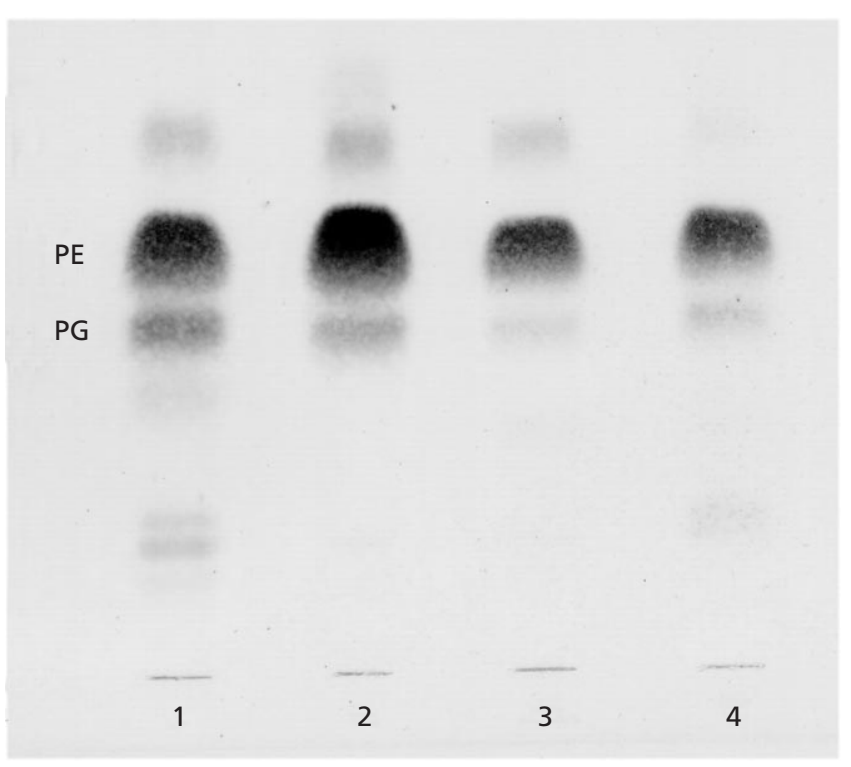

Fig. 3. TLC of polar lipids. Lanes: 1, Burkholderia cepacia DSM $7288^{\top} ; 2$, strain SPS $1037^{\top} ; 3$, Delftia acidovorans DSM $39^{\top} ; 4$, Chromobacterium violaceum DSM $30191^{\top}$. PE, phosphatidylethanolamine; PG, phosphatidylglycerol.

sulfate and thiosulfate in the medium during growth of strain SPS- $1037^{\mathrm{T}}$ indicated that thiosulfate was oxidized to sulfate.

\section{Polar lipid, respiratory quinone and fatty acid composition}

The polar lipid pattern on TLC revealed the presence of phosphatidylethanolamine and phosphatidylglycerol among other minor phospholipids (Fig. 3).
Table 3. Mean fatty acid composition of strain SPS- $1037^{\top}$ after growth at $55^{\circ} \mathrm{C}$

\begin{tabular}{|lc|}
\hline Fatty acid & Proportion (\%) \\
\hline $8: 03-\mathrm{OH}$ & $0 \cdot 8$ \\
$15: 1 \omega 6 c$ & $1 \cdot 3$ \\
$15: 0$ & $5 \cdot 3$ \\
$16: 1 \omega 7 c$ & $12 \cdot 4$ \\
$16: 1 \omega 7$ & $1 \cdot 9$ \\
$16: 1 \omega 5 c$ & $0 \cdot 4$ \\
$16: 0$ & $34 \cdot 7$ \\
iso $17: 1 \omega 9 c$ & $0 \cdot 4$ \\
$17: 0$ cyclo & $11 \cdot 8$ \\
$17: 0$ & $18 \cdot 0$ \\
$18: 1 \omega 7 c$ & $6 \cdot 1$ \\
$18: 0$ & $2 \cdot 7$ \\
Unknown* & $2 \cdot 6$ \\
$19: 0$ cyclo $\omega 8 c$ & $0 \cdot 9$ \\
\hline
\end{tabular}

* Unknown fatty acid with equivalent chain length of $18 \cdot 841$.

The same pattern was found in other $\beta$-Proteobacteria examined during this study, namely the type strains of Delftia acidovorans (DSM 39 $)$, Burkholderia cepacia (DSM $7288^{\mathrm{T}}$ ) and Chromobacterium violaceum (DSM $30191^{\mathrm{T}}$ ). The major respiratory lipoquinone was ubiquinone 8 . The fatty acid composition was fairly simple and was dominated by 16:0 (35\%) and 17:0 $(18 \%)$, but unsaturated fatty acids were present in large relative proportions at the optimum growth temperature (Table 3).

\section{Phylogenetic analysis: gene sequence comparison}

An almost complete 16S rRNA gene sequence of $1493 \mathrm{nt}$ in length was determined for the new isolate strain SPS-1037 $7^{\mathrm{T}}$. Phylogenetic analyses based on a data set comprising 1096 unambiguous nucleotides between positions 38 and 1400 [Escherichia coli positions (Brosius et al., 1978)] showed the new isolate to cluster within the radiation of the $\beta$-subclass of the Proteobacteria (Fig. 4). Pairwise 16S rRNA gene sequence comparisons with representatives of validly described taxa within the $\beta$-subclass of the Proteobacteria gave similarity values in the range 86.9 to $93.4 \%$. The highest $16 \mathrm{~S}$ rRNA gene sequence similarity value between the sequence of strain SPS-1037 and 16S rRNA gene sequences available in the public databases was found to strain ac- 15 at $96.6 \%$ when 1369 positions were directly compared. The $16 \mathrm{~S}$ rRNA gene sequence of strain SPS- $1037^{\mathrm{T}}$ was compared to the partial sequences of other known thermophiles within the $\beta$-subclass of the Proteobacteria. Although these reference sequences were as short as $142 \mathrm{nt}$, values of $\sim 85 \%$ similarity were obtained for the comparisons to Thermothrix azorensis (U59127), Thermothrix thiopara (U61284) and Thiomonas cuprina (U67162). 


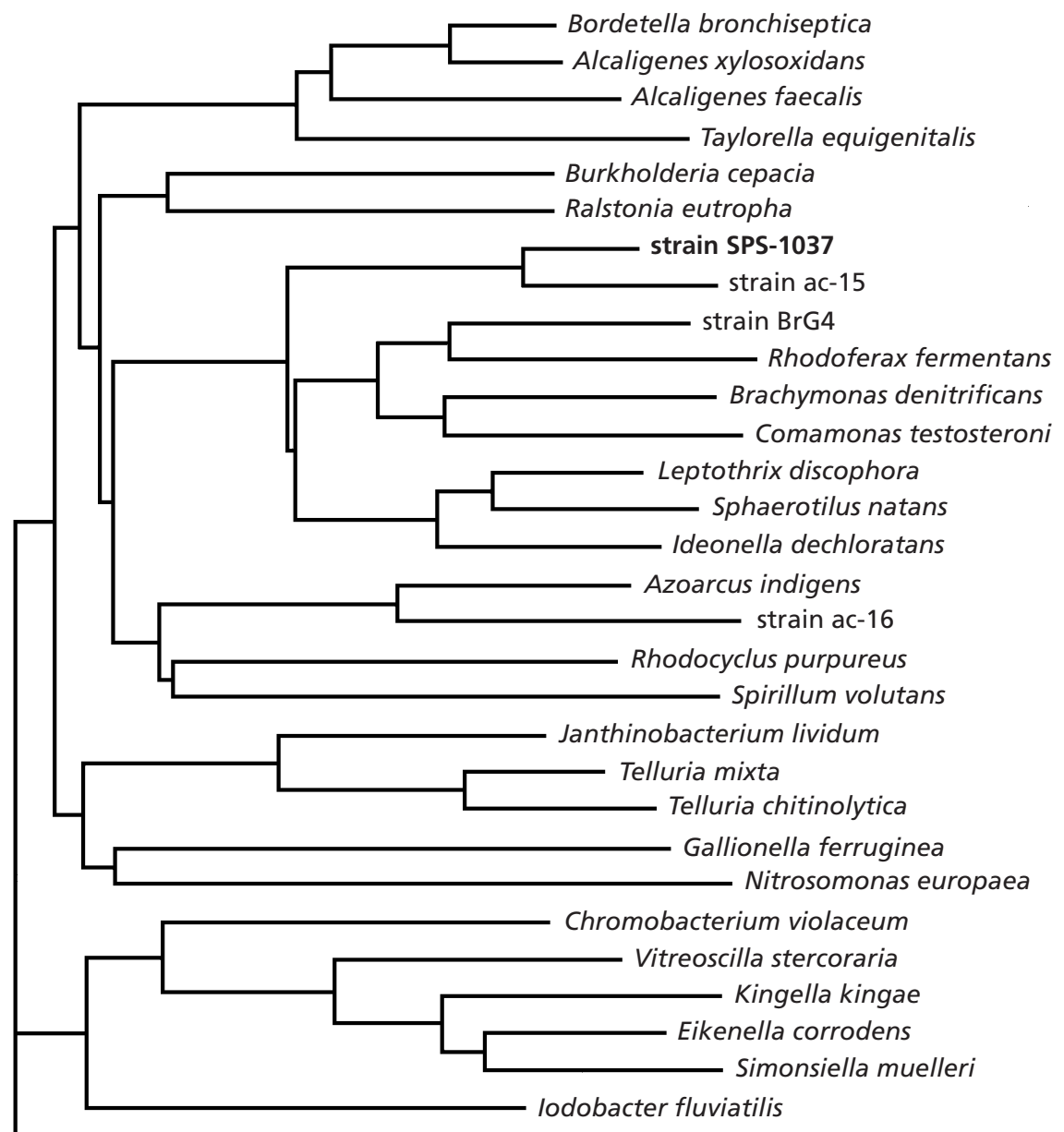

Escherichia coli

$10 \cdot 0$

Fig. 4. $16 \mathrm{~S}$ rRNA gene sequence-based neighbour-joining phylogenetic tree showing the position of the new isolates within the radiation of representative species of the $\beta$ subclass of the Proteobacteria. The position of the root was determined by the inclusion of Escherichia coli as an outgroup sequence. The scale bar represents 10 inferred nucleotide substitutions per 100 nucleotides.

\section{DISCUSSION}

Many thermophilic species were initially isolated on media containing low concentrations of yeast extract and tryptone, but the repeated use of these media generally results in the isolation of organisms that are already known. Aerobic spore-formers and species of the genera Thermus and Meiothermus had been isolated before from the hot spring at São Pedro do Sul on yeast extract/tryptone media (Santos et al., 1989; Nobre et al., 1996). $\gamma$-Irradiation of samples resulted in the isolation of bacteria of the genera Deinococcus and Rubrobacter from the same site (Ferreira et al., 1997, 1999). Recently, we began using media normally recommended for other purposes in an attempt to isolate different aerobic thermophilic bacteria from this hot spring. Strain SPS- $1037^{\mathrm{T}}$ was isolated on a medium composed of a mixture of Thermus/Kligler's iron agar but several attempts to recover other isolates from the same site failed, so the isolation of this organism may have been fortuitous.

Phylogenetic analysis of strain SPS- $1037^{\mathrm{T}}$ shows that this organism and a strain isolated several years ago, designated ac-15 (Nold et al., 1996), from Octopus Spring in Yellowstone National Park, cluster together within the $\beta$-Proteobacteria (Fig. 4). These two strains share low $(<94.0 \%)$ 16S rRNA gene sequence similarity with any of the previously described taxa within the $\beta$-subclass of the Proteobacteria and can therefore be considered to represent a lineage of genus status within this group. 16S rRNA gene sequence similarity values $\sim 85 \%$ excluded strains SPS- $1037^{\mathrm{T}}$ and ac- 15 from membership of the genera with previously described thermophilic species within the $\beta$-subclass of the Proteobacteria, namely Thermothrix and Thiomonas.

The characteristics of strain ac-15 have not been 
described and so are not available for comparison with those of strain SPS-1037 ${ }^{\mathrm{T}}$, its nearest known relative. With a $16 \mathrm{~S}$ rRNA gene sequence difference of $\sim 3 \%$ these two strains could represent distinct species of a novel genus. Although both strains represent a distinct lineage within the $\beta$-Proteobacteria, and strain SPS$1037^{\mathrm{T}}$ has a high temperature range for growth compared to many species of this subclass, it resembles, in many respects, other mesophilic species of the $\beta$ Proteobacteria. The fatty acid composition, the lipoquinones and the polar lipid pattern are typical of the $\beta$-Proteobacteria. This organism does not grow on any of the sugars or polyols tested and does not appear to have a functional glycolytic pathway for the breakdown of sugars into pyruvate. The inability to grow on carbohydrates is known in the $\beta$-Proteobacteria, such as in species of the genera Delftia and Thiomonas (Moreira \& Amils, 1997); however, the reason for the inability to utilize carbohydrates is, to our knowledge, not known. Like many other $\beta$-Proteobacteria, strain SPS- $1037^{\mathrm{T}}$ is able to obtain utilizable energy from the oxidation of sulfur compounds in the presence of utilizable organic carbon sources, but the organism does not appear to be chemolithoautotrophic under the conditions examined. The abundance of species of $\beta$-Proteobacteria that carry out sulfur oxidation of one type or another has lead to the hypothesis that it represents an ancient property of these bacteria (Moreira \& Amils, 1997).

On the basis of phenotypic characteristics and $16 \mathrm{~S}$ rRNA gene sequence analysis we propose that strain SPS- $1037^{\mathrm{T}}$ represents a new species of a new genus for which the name Tepidimonas ignava is proposed.

\section{Description of Tepidimonas gen. nov.}

Tepidimonas (Te.pi.di.mo'nas. L. adj. tepidus warm; Gr. n. monas unit, monad; M.L. fem. n. tepidimonas warm monad).

Forms rod-shaped cells that stain Gram-negative. Endospores are not formed. Slightly thermophilic. Strictly aerobic; oxidase- and catalase-positive. Fatty acids are straight-chained; major phospholipids are phosphatidylethanolamine and phosphatidylglycerol; ubiquinone 8 is the major respiratory quinone. Reduced sulfur compounds are oxidized to sulfate. Chemolithoheterotrophic. Organic acids and amino acids are used as carbon and energy sources, but sugars and polyols are not assimilated. The type species is Tepidimonas ignava.

\section{Description of Tepidimonas ignava sp. nov.}

Tepidimonas ignava (ig.na'va. L. adj. ignavus lazy, pertaining to the organism's trait not to use sugars for growth).

Forms short rod-shaped cells $1 \cdot 0-2 \cdot 0 \mu \mathrm{m}$ in length and $0.5-1.0 \mu \mathrm{m}$ in diameter. Gram stain is negative. The cells are motile by one polar flagellum. Colonies on
Degryse 162 medium are not pigmented and are 1-2 $\mathrm{mm}$ in diameter after $60 \mathrm{~h}$ growth. Growth occurs above $35^{\circ} \mathrm{C}$ and below $65^{\circ} \mathrm{C}$; the optimum growth temperature for strain SPS- $1037^{\mathrm{T}}$ is $50-55^{\circ} \mathrm{C}$. The optimum $\mathrm{pH}$ is between $\mathrm{pH} 7.5$ and 8.5 ; growth does not occur at $\mathrm{pH} 6.0$ or $\mathrm{pH} 10 \cdot 0$. The major fatty acids are $\mathrm{C} 16: 0$ and $\mathrm{C17}: 0$; unsaturated fatty acids are also present in large amounts. Ubiquinone 8 is the major respiratory quinone. Strain SPS- $1037^{\mathrm{T}}$ is strictly aerobic, and positive for cytochrome oxidase and catalase. Yeast extract or growth factors are required for growth. Strain SPS $-1037^{\mathrm{T}}$ does not reduce nitrate to nitrite. Thiosulfate is oxidized to sulfate and serves as an energy source coupled to the assimilation of organic substrates. Strain SPS- $1037^{\mathrm{T}}$ is not chemoautotrophic on reduced sulfur compounds. Urease is positive; methyl red, Voges-Proskauer and indole are negative. Hide powder is degraded, but xylan, starch, casein, elastin and fibrin are not. Several amino acids and organic acids are utilized for growth but strain SPS- $1037^{\mathrm{T}}$ does not utilize hexoses, disaccharides, pentoses or polyols. The DNA of strain SPS $-1037^{\mathrm{T}}$ has a $\mathrm{G}+\mathrm{C}$ content of $69.7 \mathrm{~mol} \%$. This bacterium was isolated from the hot spring at São Pedro do Sul in central Portugal. Strain SPS-1037 $7^{\mathrm{T}}$ has been deposited in the Deutsche Sammlung von Mikroorganismen und Zellkulturen, Braunschweig, Germany, as strain DSM $12034^{\mathrm{T}}$.

\section{ACKNOWLEDGEMENTS}

This work was supported, in part by the PRAXIS XXI Program (PRAXIS/PCNA/BIO/46/76), Portugal.

\section{REFERENCES}

Brosius, J., Palmer, M. L., Kennedy, P. J. \& Noller, H. F. (1978). Complete nucleotide sequence of a $16 \mathrm{~S}$ ribosomal RNA gene from Escherichia coli. Proc Natl Acad Sci USA 75, 4801-4805.

Caldwell, D. E., Caldwell, S. J. \& Laycock, J. P. (1976). Thermothrix thioparus gen. et sp. nov., a facultatively anaerobic facultative chemolithoautotroph living at neutral $\mathrm{pH}$ and high temperature. Can J Microbiol 22, 1509-1517.

Cashion, P., Holder-Franklin, M. A., McCully, J. \& Franklin, M. (1977). A rapid method for the base ratio determination of bacterial DNA. Anal Biochem 81, 461-466.

Das, S. K., Mishra, A. K., Tindall, B. J., Rainey, F. A. \& Stackebrandt, E. (1996). Oxidation of thiosulfate by a new bacterium, Bosea thiooxidans (strain BI-42) gen. nov., sp. nov.: analysis of phylogeny based on chemotaxonomy and $16 \mathrm{~S}$ ribosomal DNA sequencing. Int J Syst Bacteriol 46, 981-987.

Degryse, E., Glansdorff, N. \& Pierard, A. (1978). A comparative analysis of extreme thermophilic bacteria belonging to the genus Thermus. Arch Microbiol 117, 189-196.

Deutsche Sammlung von Mikroorganismen und Zellkulturen (1993). DSM Catalogue of Strains. Braunschweig, Germany: DSMZ.

Felsenstein, J. (1993). PHYLIP (phylogenetic inference package) version 3.5.1. Seattle: Departement of Genetics, University of Washington.

Ferreira, A. C., Nobre, M. F., Rainey, F. A., Silva, M. T., Wait, R., Burghardt, J., Chung, A. P. \& da Costa, M. S. (1997). Deinococcus 
geothermalis sp. nov. and Deinococcus murrayi sp. nov., two extremely radiation-resistant and slightly thermophilic species from hot springs. Int J Syst Bacteriol 47, 939-947.

Ferreira, A. C., Nobre, M. F., Moore, E., Rainey, F. A., Battista, J. R. \& da Costa, M. S. (1999). Characterization and radiation resistance of new isolates of Rubrobacter radiotolerans and Rubrobacter xylanophilus. Extremophiles 3, 235-238.

Heimbrook, M. E., Wang, W. L. L. \& Campbell, G. (1989). Staining bacterial flagella easily. J Clin Microbiol 27, 2612-2615.

Jukes, T. H. \& Cantor, C. R. (1969). Evolution of protein molecules. In Mammalian Protein Metabolism, pp. 21-132. Edited by H. N. Munro. New York: Academic Press.

Kuykendall, L. D., Roy, M. A., O’Neill, J. J. \& Devine, T. E. (1988). Fatty acids, antibiotic resistance, and deoxyribonucleic acid homology groups of Bradyrhizobium japonicum. Int J Syst Bacteriol 38, 358-361.

Maidak, B. L., Cole, J. R., Parker, C. T., Jr \& 11 other authors (1999). A new version of the RDP (Ribosomal Database Project). Nucleic Acids Res 27, 171-173.

Mesbash, M., Premachandran, U. \& Whitman, W. B. (1989). Precise measurement of the $\mathrm{G}+\mathrm{C}$ content of deoxyribonucleic acid by high-performance liquid chromatography. Int $J$ Syst Bacteriol 39, 159-167.

Moreira, D. \& Amils, R. (1997). Phylogeny of Thiobacillus cuprinus and other mixotrophic Thiobacilli: proposal for Thiomonas gen. nov. Int J Syst Bacteriol 47, 522-528.

Nobre, M. F., Carreto, L., Wait, R., Tenreiro, S., Fernandes, O., Sharp R. J. \& da Costa, M. S. (1996). Fatty acid composition of the species of the genera Thermus and Meiothermus. Syst Appl Microbiol 19, 303-311.

Nold, S. C., Kopczynski, E. D. \& Ward, D. M. (1996). Cultivation of aerobic chemoorganotrophic proteobacteria and gram-positive bacteria from a hot spring microbial mat. Appl Environ Microbiol 62, 3917-3921.

Nunes, O. C., Donato, M. M. \& da Costa, M. S. (1992). Isolation and characterization of Rhodothermus strains from S. Miguel, Azores. Syst Appl Microbiol 15, 92-97.

Odintsova, E. V., Jannasch, H. W., Mamone, J. A. \& Langworthy, A. (1996). Thermotrix azorensis sp. nov., an obligately chemo- lithoautotrophic, sulfur-oxidizing, thermophilic bacterium. Int $J$ Syst Bacteriol 46, 422-428.

Prado, A., da Costa, M. S. \& Madeira, V. M. C. (1988). Effect of growth temperature on the lipid composition of two strains of Thermus sp. J Gen Microbiol 134, 1653-1660.

Rainey, F. A., Ward-Rainey, N., Kroppenstedt, R. M. \& Stackebrandt, E. (1996). The genus Nocardiopsis represents a phylogenetically coherent taxon and a distinct actinomycete lineage: proposal of Nocardiopsaceae fam. nov. Int J Syst Bacteriol 46, 1088-1092.

Santos, M. A., Williams, R. A. D. \& da Costa M. S. (1989). Numerical taxonomy of Thermus isolates from hot springs in Portugal. Syst Appl Microbiol 12, 310-315.

Sharp, R. J. \& Williams, R. A. D. (1988). Properties of Thermus ruber strains isolated from Icelandic hot springs and DNADNA homology of Thermus ruber and Thermus aquaticus. Appl Environ Microbiol 54, 2049-2053.

Shooner, F., Bousquet, J. \& Tyagi, R. (1996). Isolation, phenotypic characterization, and phylogenetic position of a novel, facultatively autotrophic, moderately thermophilic bacterium, Thiobacillus thermosulfatus sp. nov. Int J Syst Bacteriol 46, 409-415.

Silva, M. T. \& Macedo, P. M. (1983). The interpretation of the ultrastructure of mycobacterial cells in transmission electron microscopy of ultrathin sections. Int J Lepr Other Mycobact Dis 51, 225-234.

Silva, M. T. \& Macedo, P. M. (1987). Improved Thiéry staining for the ultrastructural detection of polysaccharides. J Submicrosc Cytol 19, 677-681.

Sörbo, B. (1987). Sulfate: turbidimetric and nephelometric methods. Methods Enzymol 143, 3-6.

Tindall, B. J. (1989). Fully saturated menaquinones in the archaebacterium Pyrobaculum islandicum. FEMS Microbiol Lett 60, 251-254.

Westley, J. (1987). Thiocyanate and thiosulfate. Methods Enzymol 143, 23-25.

Williams, R. A. D. \& da Costa, M. S. (1992). The genus Thermus and related microorganisms. In The Prokaryotes, 2nd edn, pp. 3745-3753. Edited by A. Balows and others. New York: Springer. 